17 フェライト細管による水の密X線発生の試み

岩手医科大学教養部物理学教室 佐藤英一, 他 6 名 生体の電子顕微鏡用凹凸像を撮影するために、フェライト細管を 用いて水の空入線の発生を試みた。実験装置は高電圧充電器, 極性 反転式高電圧パルサ、油拡散ポンプ、細管付きの水の空線管など からなる，高電圧パルサ内のコンデンサを充電し，蓄積された電荷 を細管內に放電させ，X線を発生させる，細管の陽陰極には水の空 X線領域にL特性線を持つチタンを採用した。実験では安定な水の 空X線の発生を確認した。なお，本研究は岩手テクノポリス財団の 研究助成により遂行されている。

\section{8 ターゲットのないX線管の基礎研究}

岩手医科大学教養部物理学教室 佐藤英一。他 5 名

真空空間からのX線の出力を目的として基礎研究用X線装置を試 作した．装置は高電圧充電器，二つの電圧出力端子を有する極性反 転式高電圧発生装置、油拡散ポンプ、X線管などよりなる、X線管 には二つの陰極があり，電子を加速し，管中心で衝突させる．実呀 では雲のような線源らしきビンホール像が得られた。このX線管 ではターゲットがないので、制動X線のみが得られるはずである。 なお、本研究は岩手テクノポリス財団の研究助成により遂行されて いる。

19 藤原 4 代遗体 1 線写真撮影成果と考察 樋口喜代治 (新潟市)

撮影(一般)

座長 いわき市立総合磐城共立病院 赤沼輝亨

20 額関節撮影の検討一第 1 報一

弘前大学医学部附属病院長内恒美，他 4 名

当院で顎関節撮影は、シュラー法(開閉口時)とオルビトラムスの 2 方向で行っている.オルビトラムスで眼窩内に下頜頭がはっき り撮影されない場合があり，ポジショニングが悪いのか，患者の状 態なのかを検討した。写真上よりシュラ一開口時の下顎窝，下顎頭 の移動した距離の計測，およびオルビトラムスに下頻頭の描出され ている状態をスコアにし，そのスコアと下類頭移動距離との関係を 調べた.スコアを1〜4に分類し、1は見えない，4がいちばん良 く見え，2，3はその中間に位置する。また，開口度(前歯間距離) を測定し、下頡頭移動距離，開口度，スコア，男女別の関係を調べ た，女性の場合、下䫓頭移動距離，開口度の大きいちがスコアが高 く，開口度が大きくても，下顎頭移動距離が小さい場合，スコアが 低いことがわかった，下影頭が12 mm以上の移動で，女性がスコア 4，男性がスコア3となり，ロを大きく開くことができても、 $12 \mathrm{~mm}$ 以上移動しない限りオルビトラムスでは，下影頭の描出がむ ずかしいことがわかった。

\section{1 頻関節撮影の検討一第 2 報一}

弘前大学医学部附属病院 大谷雄彦，他 4 名

第 1 報では、シュラー法において、下䪽頭移動距離 $12 \mathrm{~mm}$ を基 準とし報告した。しかし，女性の場合，12mm以下でもオルビトラ ムス法で下顓頭がはっきり描出されることがあり，また男性の場 合，12mm以上でも下䪽頭がはっきり描出されないことが多いとい つた原因を第 1 報の方法の他に、シュラ一開口時の下類窝と下顎 頭を結んだ距離，外耳孔中心と乳椂突起先端を結んだ距離、また頭 部側面厚、オルビトラムス撮影時のOM-lineの角度の計測を行い， スコアとの関係を検討した。 その結果，女性の場合、下頡頭が前方 より下方に大きく移動した場合、下顎頭移動距離 $12 \mathrm{~mm}$ 以下でも下 䫟頭がはっきり描出されることがあった，男性の場合，乳様突起が 大きいことが多く、下顡頭と重なり描出されにくかった。また。 OM-line $15^{\circ}$ およ゙20歳代以下の女性で下領頭がはっきり描出され ることが多かった．今後，オルビトラムス撮影時に用いる補助具の 作製等を課題とし検討していきたい。

\section{2 岩手県立病院における胸部撮影の現状}

岩手県立宮古病院 鳥居東悟，他 4 名

【目的】結核予防会の評価が高位の肺野の濃度の写真，および撮影条 件等の調查を基に岩手県立病院の施設における胸部単純撮影の条件 等を調查し、施設間の現状を把握した。特に設定管電圧、使用され たフィルム，付加フィルタに着目した。より高圧撮影化，ならびに 低被懪を付加フィルタの使用によってできるかどうかを検討した。
【結果・結論】使用管電圧は結核予防会，および当県立病院では使用 しているフィルムに合わせ，各施設ごとに設定していたが，付加フ イルタの使用の有無については予防会では100\%の使用をみたが， 当県立病院は50\%に満たない使用率であった。高エネルギ一側に 移行し，低被曝につながり医療法にもかない，また低コストで簡便 に装着できる付加フィルタを各施設の状況に合わせて利用を検討し たい.

\section{3 消化管撮影システムの垀価}

仙台赤十字病院 三浦一隆，他 4 名

【目的】上部消化管撮影において撮影システムの評洒を行うため に，基本的な特性について異なる施設間で測定を行い比較検討を 行った。

【使用機器】東芝DBA-300A，DCA-100A-100A/01

【検討項目・結果】撮影システムの構成を比較した、乞スクリ一 ン・フィルムの特性曲線をブーツストラップ法により求めた。 3散 乱線含有率を鉛ディスク法で測定し，装置自体の散乱線が20\%近 く存在することがわかった。牙被曝線量を求めた。フィルム濃度 (1.0+カブリ)になる照射線量の皮膚面における吸收線量はDCA100Aでは0.564mGy,DBA-300Aでは0.680mGyとなった。可TV 透視像の特性曲線を求めた。フフルムに比べ、CRTのダイナミッ クレンジが狭いことを確認できた．6バリウムの減弱曲線を求め， バリウムの造影効果が非常に高いことがわかった.

\section{MRI(䕎床)}

\section{3D fast spin echo法による內耳撮像}

秋田大学医学部附属病院 成田孔明, 他 4 名

【目的】3D FSE法の撮像が可能となったので、コイルの選択と撮像 条件を求めた。

【撮像条件】患者 20例. TR/TE/ETL=4200/200/32, FOV $=18 \mathrm{~cm}$, $N E X=2$, matrix $=256 \times 256$, slice thickness $=0.7 \mathrm{~mm}$.

(方法 /3-inch dual phased array coil (以下, 3inDPAC) とhead coil の深さ方向のSNRを測定し、内耳の深さ合ったcoilを決める.TR， $E T L を 一$ 定とし最適なTEを求める。回転イメージを作成する。 【結果・考察】内耳の膜迷路構造が非常に良く描出された．対象患者 20人の内耳の深さとコイル別のSNRを測定して3inDPACが一番良 い、TEの值は、アーチファクトが少なく，水成分の組織に対する コントラストを調べて，200 msecが最適であった。1 回の撮像だ けで，後は画像処理することで多方向から観察でき，またステレオ 画像，動画作成ができた。

25 contrast MRAを利用した血流動態観察について－造影威 注入速度と撮影条件の基礎的検討一

総合保原中央病院 菅野敏美，他 2 名

【目的】MR検査における血液動態撮影法は，phase shift効果を応用 したcine-PC法が挙げられるが，流速依存性や心電同期等の問題が のこる。そそこで，近年注目されているcontrast MRAを利用して， 血流動態の観察を行うべく，基礎的検討を行ったので報告する。 【使用機器】Philips GyroScan ACS-NT1.5T

【方法】血流動態を観察するうえで必要とされる撮影速度を2phase/ sec〜1phase/2secと仮定して，その範囲内に撮影できるパラメー 夕と各種条件の検討，および，良好なSNRを得るに必要な Gd DTPA濃度と、注入速度の検討を行った。

【結果】時間分解能を重視すると，組織コントラストがばらつきをみ せるが，注入速度の急速化に伴い、極端な丁、短縮がみられ，良好な SNRを得ることができる.

\section{6 subtraction併用による骨盤部造影MRA}

弘前大学医学部附属病院森田竹史, 他 6 名

骨盤部MRAは，従来造影剂を使用しないTOF法，PC法で行われ ているが，良好な血管像を得ることは困難であった．今回われわれ は、C-P型body array coil 使用し、3D MP RAGE法にて、subtraction併用による骨盤部造影MRAを閉塞性動脈硬化症の患者に対 し施行した．当院で行われてきた2D TOF法との比較では、造影 MRAはsubtractionにより脹管のartifactが軽減し，さらに蛇行した 血管や狭窄部の観察が容易となり、細い血管の描出能が向上した。 問題点として，TOF法で生じた左右側の信号差の消失，画像処理 時間の延長、検查範囲の制約があり，今後，問題点を考慮しなが 